\title{
Does a Parent-Subsidiary Structure Enhance Financing Flexibility?
}

\author{
ANAND M. VIJH *
}

\begin{abstract}
I examine whether firms exploit a publicly traded parent-subsidiary structure to issue equity of the overvalued firm regardless of which firm needs funds, and whether this conveys opposite information about firm values. Using 90 subsidiary and 37 parent SEO announcements during 1981 to 2002, I document negative returns to issuers but insignificant returns to nonissuers in both samples, and insignificant changes in combined firm value and parent's nonsubsidiary equity value in subsidiary SEOs. Firms issue equity to meet their own financing needs. My evidence contrasts with previous studies and suggests that parent-subsidiary structures do not enhance financing flexibility.
\end{abstract}

\footnotetext{
* Tippie College of Business, The University of Iowa. I wish to thank Matt Billett, Jie Cai, and Jon Garfinkel for useful comments. I am very obliged to two anonymous referees, an associate editor, and Robert Stambaugh (the editor) for many comments that substantially improved this paper. Wei Li provided assistance with data collection.
} 


\section{Does a Parent-Subsidiary Structure Enhance Financing Flexibility?}

Corporate acquisitions and divestitures have been a constant feature of the U.S. financial markets. The combination of synergistic businesses and separation of nonsynergistic businesses is believed to increase the combined value of firms. Sometimes, however, the acquiring firm seeks only a partial stake in a target firm, or the divesting firm sells only a partial stake in a divested unit. Such partial acquisitions and equity carve-outs result in a parent-subsidiary structure in which both the parent and the subsidiary stocks are publicly traded. ${ }^{1}$

This paper examines the equity issuance decisions within such parent-subsidiary structures. Specifically, I examine whether firms exploit their parent-subsidiary structure to issue equity in the overvalued firm regardless of which firm needs the proceeds, and whether such issues simultaneously convey negative information about the issuing firm and positive information about the nonissuing firm. Evidence in favor of this hypothesis would suggest that a parent-subsidiary structure can increase the combined value of the two firms by enhancing their financing flexibility. ${ }^{2}$ It would also help explain why the market reacts positively to equity carve-outs that establish a parent-subsidiary structure in the first place.

Slovin and Sushka (1997) examine a sample of 75 seasoned equity offerings (SEOs) within such structures during the period 1975 to 1993. For both parent and subsidiary SEOs, they document significantly negative excess returns to the issuing firms and significantly positive excess returns to the nonissuing firms. They also document significantly positive implied excess returns to the nonsubsidiary equity value of parent firms and wealth gains to the combined parent-subsidiary structure in the subsample of 38 subsidiary SEOs. Slovin and Sushka conclude "Gains in parent value exceed losses sustained by minority shareholders of issuing subsidiaries so, contrary to prior evidence about negative wealth effects of seasoned equity issuance, announcements of subsidiary stock offerings increase the value of the combined enterprise.” They interpret their evidence as inconsistent with the simple adverse selection hypothesis of Myers and Majluf (1984) and consistent with the strategic financing hypothesis of Nanda (1991). 
The adverse selection model of Myers and Majluf considers SEOs of stand-alone firms. They show that, on average, firms will issue stock when managers have private information that their stock is overvalued. In turn, the market will react rationally to the announcement of equity issues by lowering the stock price. Their model has two well-known implications. First, SEOs lead to a reduction in firm value. Second, the adverse market reaction leads to underinvestment in the economy as many undervalued firms do not seek equity financing for positive but relatively low net present value projects.

The strategic financing model of Nanda considers equity issues within a parent-subsidiary structure. While his discussion focuses on the first equity issue within such a structure, the equity carveout, his analysis does not depend on the existence or non-existence of a public market for the subsidiary stock. His model predictions should therefore apply to the subsequent SEO decisions. Nanda extends the Myers and Majluf framework to show that, on average, subsidiary stock issues will occur when the subsidiary assets of the parent firm are overvalued and nonsubsidiary assets are undervalued. The opposite result holds for parent stock issues. Assuming further that nonsubsidiary assets are larger, it follows that in either case the stock returns will be negative for the issuing firm and positive for the nonissuing firm. Nanda's model implications contrast with those of Myers and Majluf. First, subsidiary SEOs lead to an increase in parent firm value, and parent SEOs lead to an increase in subsidiary firm value. Second, enhanced financing flexibility reduces the underinvestment problem for firms that adopt a parent-subsidiary structure. Both models predict a decrease in the issuing firm’s value, however.

Empirically testing Nanda's model presents two challenges. First, in the context of carve-outs, separate returns to parent and subsidiary assets are not observed. Second, in the context of existing parentsubsidiary structures, application of Nanda's model assumes that funds raised in one unit can be utilized by the other unit. While the opportunity to achieve such transfer of funds at the time of carve-out is undisputed, the degree to which existing parent-subsidiary structures implement these transfers remains an empirical question. Despite these limitations, and given the importance of Nanda's results, his model has been tested in both contexts. In the case of carve-outs, Vijh (2002) tests an implication of Nanda's model that the parent stock returns should be decreasing in the ratio of overvalued subsidiary assets to undervalued nonsubsidiary assets. Vijh finds that the empirical relation is significant in the opposite 
direction. However, Schill and Zhou (2001), Mitchell, Pulvino, and Stafford (2002), and Lamont and Thaler (2003) show that in a few cases the parent stocks sell for less than their proportional holdings of subsidiary stocks after carve-outs. The existence of these so-called negative stub value cases suggests that the nonsubsidiary assets of the parent firm may be undervalued relative to the subsidiary assets, even though in an absolute sense both may be undervalued or overvalued. These carve-out studies thus provide mixed evidence in support of Nanda's model. In the case of publicly traded parent-subsidiary structures, one may expect that the ability to transfer funds across units is lower when the subsidiary firm is publicly traded. Slovin and Sushka do not provide direct evidence on fund transfer, but they do provide significant evidence of negative excess returns to issuing firms and positive excess returns to nonissuing firms.

I reexamine the wealth effects of equity issues within parent-subsidiary structures using a sample of 127 SEOs during 1981 to 2002 that are collected from the Securities Data Company (SDC) database. In the subset of 90 subsidiary SEOs, I find that the subsidiary stocks earn a significant market-adjusted average announcement excess return of $-2.01 \%$ while the parent stocks earn an insignificant $0.27 \%$ (medians $-1.73 \%$ and $-0.13 \%$ ). Given the larger size of parent firms, the combined excess return is negative but insignificant. In the subset of 37 parent SEOs, I find significant parent returns of $-2.20 \%$ and insignificant subsidiary returns of $0.56 \%$ (medians $-1.55 \%$ and $-0.73 \%$ ). This evidence suggests that in both types of SEOs, the market perceives the issuing firm to be overvalued, but perceives no significant new information concerning the nonissuing firm's value. When I examine several cuts of the data, based upon percent ownership, use of funds, type of issue, and size of subsidiary stake relative to parent equity value, the evidence remains unchanged. Further tests based on trading volume also suggest that the market perceives new information concerning issuing firm value but not nonissuing firm value.

The parent stock represents a combination of equity claims on the subsidiary and nonsubsidiary assets of the parent firm. I next examine the implied excess returns to the nonsubsidiary equity value of parent firms in subsidiary SEOs, which are predicted to be positive by Nanda's model. This examination presents further challenges as his model assumes no debt, whereas the sample firms always have debt. Since the excess returns to parent and subsidiary debt are unobservable, my calculations necessarily ignore debt. This leads to unrealistic negative or small positive implied nonsubsidiary equity values in 
some cases. But within the subset of 63 subsidiary SEOs for which nonsubsidiary equity value is greater than subsidiary equity value, as modeled by Nanda, I find insignificant mean and median excess returns of $0.43 \%$ and $-0.55 \%$. Within the subset of 15 cases for which nonsubsidiary equity value is smaller than subsidiary equity value, but positive, I find mean and median excess returns of $17.02 \%$ and $1.57 \%$. For the combined sample of 78 cases, the mean and median excess returns equal $3.62 \%$ and $0.13 \%$. The stark difference between the mean and median values arises from a few very large returns earned by firms with small positive nonsubsidiary equity value (computed by ignoring debt value). In fact, as shown later in Figure 1, the evidence of positive nonsubsidiary equity returns in subsidiary SEOs based on mean returns is driven by the top decile of the combined sample ranked by the ratio of subsidiary equity value to total equity value of the parent firm. Within the remaining nine deciles, there is no such evidence. A fair assessment of the combined evidence is that these returns are insignificant.

To summarize, I find that issuing firms earn significantly negative announcement excess returns from both parent and subsidiary SEOs. This evidence is consistent with the Myers and Majluf model and similar to evidence from studies of SEOs by stand-alone firms. I also find that nonissuing firms earn insignificant announcement returns from both parent and subsidiary SEOs, combined firms earn insignificant returns in subsidiary SEOs, and the nonsubsidiary equity value of parent firms changes by an insignificant amount in subsidiary SEOs. These additional results contrast with the results documented by Slovin and Sushka over a different period, and are inconsistent with the existence of strategic financing within a publicly traded parent-subsidiary structure. The predictions of Nanda's model do not apply to such structures, which may be due to the difficulty of transferring funds across firms in such structures.

I therefore examine the likely incidence of fund transfer between firms. The stated uses of SEO proceeds rarely mention repayment of existing debt or issuance of new debt to an affiliate firm, which is inconsistent with common transfers of funds. I analyze the motivations for the three main types of equity issues: a parent primary issue, a subsidiary primary issue, and a subsidiary secondary issue of stock held by the parent. Using a multinomial probit model, I examine the role of prior-year excess returns, which are often used as a measure of potential overvaluation, and current and last year's financing deficits, which I propose as a measure of the need for funds. A parent firm's higher prior-year returns and 
financing deficits are significant factors in explaining parent primary issues, and a subsidiary firm’s higher prior-year returns and financing deficits are significant factors in explaining subsidiary primary issues. The evidence on financing deficits does not support the strategic financing hypothesis, which assumes that funds can be transferred across firms, so the choice between issues is mainly guided by overvaluation considerations. Regarding subsidiary secondary issues, I find that neither potential overvaluation nor the need for funds is a significant factor. On average, subsidiary secondary issues occur when the parent deficit is negative (i.e., a surplus), the subsidiary deficit is small, and both the parent and subsidiary prior-year returns are also small. Further investigation of media reports and differences in parent and subsidiary industry classifications suggests that subsidiary secondary stock issues held by the parent firms are motivated by divestiture considerations.

In the remainder of the paper, Section I presents data and methods, and the stated uses of SEO proceeds. Section II examines the market reaction to SEO announcements within a parent-subsidiary structure. Section III analyzes the motives for different types of issues, and Section IV concludes.

\section{Data and Methods}

\section{A. Sample of SEOs}

I obtain my sample of publicly traded parent-subsidiary structures established by carve-outs and partial acquisitions from the SDC Mergers and Acquisitions and Global New Issues databases. I identify a sample of 410 carve-outs and 376 partial acquisitions during 1980 to 2002, such that both the subsidiary and the parent firm are listed on the Center for Research in Security Prices (CRSP) database on the completion date. For each of these parent-subsidiary structures, I search the SDC database to identify

subsequent SEOs by subsidiary and parent firms before December 2002 or a known second event date. ${ }^{3}$ The SDC database also provides the Securities and Exchanges Commission (SEC) filing date, the issue date, the number of shares issued, the mix of primary and secondary shares for each SEO, and the initial ownership at the time of carve-out or acquisition.

I examine media reports on the Factiva system surrounding the SEC filing date to identify the first report date of the equity offering. The SEO announcement date is the earlier of the first media report 
date and the filing date. I determine the current ownership of subsidiary stock by the parent firm by using media reports and SEC filings. I exclude cases for which I cannot find ownership information or for which ownership is lower than 25\%. The media reports also provide the intended uses of SEO proceeds given by firm management and the identity of selling shareholders in the case of secondary offerings. I exclude cases in which the parent SEO is mainly a secondary issue (at least $80 \%$ of shares issued), or where the subsidiary SEO is mainly a secondary issue and the stock is sold by a shareholder other than the parent firm. Finally, I exclude cases such that the market value of outstanding subsidiary stock is less than $5 \%$ of the market value of parent stock before announcement, or such that either stock price is under \$3. The net result is a sample of 90 subsidiary and 37 parent SEOs.

\section{B. Sample Description}

Panel A of Table I shows that about one-fourth of SEOs in my sample are announced during 1981 to 1990, with three-fourths announced during 1991 to 2002. The vast majority occur within parentsubsidiary structures established by carve-outs. Panel B shows summary statistics separately for the subsamples of subsidiary SEOs and parent SEOs. The median market value of equity for subsidiary firms before announcement equals \$406 million in the first case and \$344 million in the second case. The corresponding parent values equal \$1,178 million and \$1,557 million. The median size ratio of subsidiary to parent market value equals 0.44 for subsidiary SEOs and 0.23 for parent SEOs. The median ratio of parent stake to parent market value equals 0.25 in the first case and 0.12 in the second case.

- Place Table I about here -

The subsidiary SEOs raise an average of \$177 million, while the parent SEOs raise an average of \$336 million. Overall, my sample includes equity offerings worth $\$(177 \times 90+336 \times 37)=\$ 28,362$ million. As a proportion of existing firm value, the subsidiary issues raise an average of $25 \%$, while the parent issues raise $16 \%$. It is remarkable that carve-outs and subsequent SEOs are much larger than the average equity issues. For comparison, the average IPO/SEO during 1975 to 1989 has an offer value of \$35 million in 1991-dollar terms in a sample of 8,455 issues analyzed by Loughran and Ritter (1995). 
The parent holds an average of $57 \%$ of the subsidiary stock in subsidiary SEOs, and $58 \%$ in parent SEOs. Parents hold a majority stake in the subsidiary firm in $63 \%$ of all cases. When I examine issue types, if at least $80 \%$ of offered shares are new shares, then I describe an issue as a primary issue. Similarly, if at least $80 \%$ of offered shares are existing shares held by a large shareholder, then I describe an issue as a secondary issue. I describe the remaining cases as mixed issues. ${ }^{4}$ Panel B of Table I shows that 42 subsidiary SEOs are primary issues, 32 are secondary issues (by parent), and 16 are mixed issues. In addition, 34 parent SEOs are primary issues and three are mixed issues. Panel B also shows that in both subsidiary and parent SEOs the subsidiary firms have higher growth opportunities based on a lower bookto-market ratio than parent firms. Finally, at the time of SEO, the subsidiary firms have been publicly traded for a median 1.88 years in the case of subsidiary SEOs and 1.92 years in the case of parent SEOs.

My sample spans a different time period from Slovin and Sushka and differs in a few other respects. First, I exclude cases in which subsidiary value is less than $5 \%$ of parent value or either stock is priced under \$3. Slovin and Sushka do not report such criteria. I argue that subsidiary stock financing is a less credible financing alternative to parent stock financing when the subsidiary is small relative to the parent. Second, Slovin and Sushka require that the parent own at least 50\% interest in the subsidiary, whereas I require that the parent own at least 25\%. I argue that parent firms exercise sufficient control to influence the subsidiary firm’s financing decisions with ownership levels between 25\% and 50\% (average 35.8\%) for the following reasons. First, in other contexts, Morck, Shleifer, and Vishny (1988) and Weston (1979) argue that insiders exercise effective control over their firms with similar ownership levels. Second, 12 out of 34 subsidiary SEOs with parent ownership between 25\% and 50\% are secondary issues, where the parent chose the subsidiary stock financing alternative, and thus parent control is not an issue. This alternative existed in other cases such as parent primary issues. However, I also examine the remaining 22 subsidiary and 13 parent SEOs for direct evidence on parent control of the subsidiary. In 28 cases I find the relevant SEC filings. In all 28 cases one or more directors on the subsidiary's board are also officers or directors of the parent. This is not surprising as in most cases the subsidiary was fully owned and controlled by the parent before carve-out. Third, I find no evidence of stand-still agreements or other arrangements that limit parent control over issuing subsidiary stock. Overall, I find that the parent 
firms had sufficient control over the subsidiary firms with ownership between $25 \%$ and $50 \%$ to influence its financial decision making, and that a subsidiary stock issue was a credible financing alternative available to them. ${ }^{5}$

\section{Stated Uses of SEO Proceeds}

Table II summarizes the stated reasons for equity issuance in 74 subsidiary SEOs and 28 parent SEOs retrieved from media reports. General corporate purposes is the most common reason, given in 32 subsidiary SEOs and 20 parent SEOs, and investments is the second most common reason, given in 32 and 16 cases, respectively. Reducing debt is the third most common reason, given in 28 subsidiary SEOs and 18 parent SEOs. Since the strategic financing hypothesis assumes transfer of proceeds across units, I examine this reason in further detail. Reducing debt owed to the parent is explicitly mentioned in five subsidiary SEOs, and using the proceeds for subsidiary purposes is mentioned in only one parent SEO. In fact, the subsidiary is almost never mentioned by name in media reports on parent SEOs. In about half of the subsidiary primary issues the debt is linked to a specific acquisition or investment project, so it cannot be debt owed to the parent. In the remaining cases the language is quite general, and it is possible that in some of these cases the subsidiary intends to repay debt owed to the parent even when this is not explicitly mentioned. It is also possible that in some cases subsidiary debt is owed to other parties but is backed by the parent, in which case reducing such debt may eliminate a contingent claim on the parent. However, it is fair to say that there is not much direct support for the strategic financing hypothesis based on anecdotal evidence of the transfer of proceeds.

It may be argued that a transfer of proceeds is not necessary in the case of subsidiary secondary SEOs, as the proceeds flow directly to the parents. For this reason, I later examine returns separately for this subset of SEOs. Note, however, that the parent's desire to divest the subsidiary stake is another common reason, given in 16 subsidiary secondary and four subsidiary mixed issues. One may argue that subsidiary secondary issues by the parent always involve some features of divestitures, or dissolution of the hypothetically advantageous financing structure.

- Place Table II about here - 


\section{Calculation of Excess Returns}

The first concern relates to the length of the announcement period. In 19 cases the first announcement date (denoted by $A D$ ) is a media report date, in 40 cases it is the SEC filing date, and in 68 cases it is the joint media report date and SEC filing date. The media reports can be from the Dow Jones News Service, PR Newswires, Select Federal Filings Newswires, the Wall Street Journal, and other sources on Factiva. These reports arrive throughout the day from early morning to late evening. For media reports earlier in the day, it is possible that there was some news on the previous day, and for media reports later in the day, the news likely impacts prices on the following day. For first announcement dates that are SEC filing dates, the news may impact prices on that day or on the following day, depending on when the report is filed. I therefore use an inclusive three-day announcement window, from $A D-1$ to $A D+1$, which is unlikely to miss any part of the market reaction. Moreover, the majority of my sample starts as carve-outs analyzed by Vijh (2002), who documents a significant market reaction on $A D-1$ with a larger sample. However, following an alternative procedure, I also report excess returns over a two-day announcement window, from $A D$ to $A D+1$, as a robustness check.

I measure the market reaction to SEOs using market-adjusted excess returns. I subtract the cumulative market returns over an appropriate test period from the cumulative stock returns. I use this procedure since SEO announcements are preceded by a strong price run-up during the previous year, which imparts downward bias to excess returns calculated using the alternative market-model procedure. I measure the combined excess return by adding the parent excess return weighted by the market value of parent stock and the subsidiary excess return weighted by the market value of subsidiary stock held by outside shareholders (i.e., excluding parent ownership). In addition to excess returns, I calculate excess trading volume of each stock by subtracting the average three-day trading volume over $A D$-160 to $A D-40$ from announcement-period trading volume. I calculate all $t$-statistics using the cross-sectional distribution of excess returns or excess trading volumes. In some places, I report additional tests of statistical significance, such as z-statistics calculated from the numbers of positive and negative returns. 


\section{The Market Reaction to SEO Announcements within a Parent-Subsidiary Structure}

\section{A. Subsidiary SEOs}

Table III, Panel A, shows that the 90 subsidiary firms earn an average market-adjusted three-day excess return of $-2.01 \%$ on the announcement of their own SEOs, significant at the $1 \%$ level with a $t$ statistic of -3.01 . The median excess return and $z$-statistic are $-1.73 \%$ and -2.74 . This return compares favorably with the excess return of $-2.32 \%$ for 1,884 SEOs during 1974 to 1990 documented by Bayless and Chaplinsky (1996). The parent three-day excess return has insignificant average and median values of $0.27 \%$ and $-0.13 \%$. Given the smaller size of subsidiary firms relative to parent firms, the combined excess return has negative but insignificant mean and median values of $-0.11 \%$ and $-0.37 \%$. The two-day excess returns present a similar picture, with average values of $-1.99 \%, 0.46 \%$, and $0.10 \%$ for subsidiary, parent, and combined firms (median values $-1.62 \%, 0.08 \%$, and $-0.26 \%$ ).

- Place Table III about here -

During a 250-day period ending on $A D$-2, the subsidiary firms and parent firms earn significant excess returns of $62.79 \%$ and $24.03 \%$ ( $t$-statistics 5.17 and 3.73). Positive prior returns have been used in the finance literature as a measure of overvaluation, an indicator of emerging positive net-present-value opportunities, or a sign of improving performance. This evidence does not suggest undervaluation of parent stocks at the time of subsidiary SEOs.

My evidence contrasts with that of Slovin and Sushka. First, they document significantly positive excess returns to subsidiary firms and significantly negative excess returns to parent firms during the prior year, while I find significantly positive excess returns in both cases. Second, they document significant announcement excess returns of $-4.06 \%$ and $1.91 \%$ to subsidiary and parent firms, while I find $-2.01 \%$ and $0.27 \%$, significant only in the first case. Third, they find that the combined returns are significantly positive, while I find that the combined returns are insignificant. Fourth, they report that for their subsample of 33 events with negative subsidiary returns, there are 26 positive returns to parents (79\% and significant). In comparison, I find that the corresponding figures in my sample are $45 \%$ with three-day returns and $48 \%$ with two-day returns, amounting to less than $50 \%$ in each case. Overall, they find that 
equity carve-outs and subsidiary stock issues have equivalent positive effects on parent value and suggest that the choice between parent versus subsidiary equity issuance reflects differential and opposite private information about the two firms as implied by the strategic financing hypothesis. However, my evidence suggests that subsidiary stock issues only convey adverse information about the issuing firm as in the Myers and Majluf framework, providing no significant new information about the nonissuing firms. My evidence also suggests that subsidiary SEOs do not increase combined shareholder wealth.

For further evidence on the informativeness of subsidiary SEO announcements, I examine changes in trading volume. Karpoff (1987) surveys several articles that show that price changes and trading volume changes are positively related. Panel A of Table III shows that the announcement trading volume of subsidiary firms is $27.45 \%$ higher than the benchmark trading volume, while there is no significant change in the trading volume of parent firms. This further suggests that on the whole there is no statistically significant new information concerning parent firms (despite their ownership of subsidiary stock, for which there is significant new information).

\section{B. Parent SEOs}

Panel B of Table III shows that parent firms earn significant market-adjusted three-day announcement excess returns that average $-2.20 \%$ from 37 parent SEOs, while subsidiary firms earn an insignificant $0.56 \%$ ( $t$-statistics -2.76 and 0.44 ). The median values of $-1.55 \%$ and $-0.73 \%$ confirm that issuer returns are significantly negative and nonissuer returns are indistinguishable from zero. For the subsample of 24 events with negative parent returns, I find 10 positive subsidiary returns, or $42 \%$, which compares with a figure of $70 \%$ reported by Slovin and Sushka. Since the issuing parents are larger than the nonissuing subsidiaries, the combined excess returns of $-1.92 \%$ are significantly negative ( $t$-statistic -2.56). The two-day returns follow the same pattern as the three-day returns, and the prior-year returns average $42.63 \%$ for issuing parents and $25.95 \%$ for nonissuing subsidiaries ( $t$-statistics 3.29 and 1.89 ). The excess announcement-period trading volume averages a significant $85.06 \%$ for parents and an insignificant $18.62 \%$ for subsidiaries. 
In both panels of Table III, the evidence is consistent with the adverse selection hypothesis, but inconsistent with the strategic financing hypothesis. Results in Panel B also contrast with Slovin and Sushka, who document significant announcement excess returns averaging $-2.68 \%$ for parents and $1.55 \%$ for subsidiaries, and negative but insignificant prior-year excess returns averaging $-6.72 \%$ for subsidiaries.

\section{Cross-Sectional Patterns}

Table IV shows the announcement excess returns for several subsets of data. The first subsets are formed by the parent ownership of the subsidiary firm (higher than 50\%, or between $25 \%$ and $50 \%$ ). The second subsets are formed by issue type (primary, secondary, or mixed). The third subsets in the case of subsidiary SEOs are formed by whether the parent receives some of the proceeds by selling subsidiary shares or by later repayment of parent debt by the subsidiary. The fourth subsets in the case of subsidiary SEOs are formed by whether the subsidiary stake value is less than or greater than the parent equity value (which can be financed with debt in addition to equity). The last subsets in both cases are formed by whether the ratio of subsidiary stake value to parent equity value is below or above the median.

- Place Table IV about here -

The following results emerge. First, some of the sample sizes become quite small. As a result, the mean returns are more likely to be driven by outliers and it becomes necessary to examine both the mean and median returns. ${ }^{6}$ Second, the difference between subset returns is insignificant and therefore not shown. Third, the mean issuer return is negative in all 17 subsets of Panels A and B, and significant in 12 subsets. Fourth, the mean nonissuer return is always insignificant, and the median nonissuer return is negative in 10 subsets. Fifth, the mean combined return in subsidiary SEOs is more often negative than positive, and the median combined return is negative in all subsets except one. ${ }^{7}$

Finally, I argue that subsidiary secondary issues by the parent are the more likely strategic financing alternative available to parent firms than subsidiary primary issues. Parents require little compliance from the subsidiary management to sell their own holdings of subsidiary shares, and they receive the related proceeds. However, Table IV, Panel A, shows that the mean parent returns and 
combined returns for the subsidiary secondary issues equal an insignificant $0.03 \%$ and $-0.05 \%$, with medians of $-1.08 \%$ and $-0.97 \%$, which are lower than in the aggregate sample in three out of four cases. A related set of issues are those in which the parent receives some of the proceeds from a subsidiary SEO as defined in Table IV. The evidence for these issues remains insignificant.

\section{Implied Excess Returns to Nonsubsidiary Equity Value of Parent Firms}

Nanda’s strategic financing model predicts that the excess returns to nonsubsidiary equity value of parent firms are positive following the announcement of subsidiary SEOs. In support of this prediction, Slovin and Sushka document a mean excess return of 3.50\% (t-statistic 6.69; first quartile, median, and third quartile values $0.84 \%, 2.50 \%$, and 5.23\%). I next examine these returns within my sample.

Nanda’s model has two important characteristics. First, he assumes that nonsubsidiary asset value of the parent firm exceeds subsidiary asset value. This assumption is necessary for some of his results to follow. Second, he assumes an all-equity firm so that assets become synonymous with equity (or stock). This is not just a modeling convenience. Allowing for debt in the model can lead to different predictions, such as the existence of debt issues to finance the parent or subsidiary projects. It also leads to problems in empirical estimation as the market value of debt and other liabilities is rarely observed. Following this assumption of an all-equity firm, I estimate the nonsubsidiary equity value of the parent firm as

$$
M V_{\text {par sub equity }}=\alpha \times M V_{\text {subequity }}, \quad M V_{\text {par nonsub equity }}=M V_{\text {par equity }}-M V_{\text {par subequity }}
$$

Here, $M V$ denotes the market value and $\alpha$ denotes the parent's fractional ownership of subsidiary equity. The subscripts par equity and sub equity refer to the observed market value of all outstanding equity of parent and subsidiary firms, and the subscripts par sub equity and par nonsub equity refer to the implied market value of subsidiary and nonsubsidiary parts of the total equity of the parent firm. Using XRET to denote the excess returns, I next calculate the implied excess return to the nonsubsidiary equity value of the parent firm (in short, the nonsubsidiary equity return) as

$$
X R E T_{\text {par nonsub equity }}=\left(X R E T_{\text {par equity }} \times M V_{\text {par equity }}-X R E T_{\text {subequity }} \times M V_{\text {par sub equity }}\right) / M V_{\text {par nonsub equity }}
$$

Unfortunately, this procedure does not yield a nonsubsidiary equity return in 12 subsidiary SEOs and one parent SEO, as the nonsubsidiary equity value calculated using (1) turns out to be a negative number. This 
is the result of necessarily ignoring debt in these computations. For example, a hypothetical parent firm with an equity value of $\$ 100$ and a debt value of $\$ 100$ may own a $\$ 150$ equity stake in a subsidiary, in which case the nonsubsidiary equity value calculated using (1) would equal $-\$ 50$, and it would be infeasible to calculate or interpret the nonsubsidiary equity value or return. ${ }^{8}$

Table V shows the implied excess returns to nonsubsidiary equity value of the parent firm in two regions. The first region for subsidiary SEOs includes 63 cases for which nonsubsidiary equity value is greater than subsidiary equity value as modeled by Nanda. Panel A shows that the three-day excess returns in this region have median and mean values of $-0.55 \%$ and $0.43 \%$ ( $p$-values 0.72 and 0.61 ). Only $44 \%$ of the returns are positive. The second region for subsidiary SEOs includes 15 cases for which nonsubsidiary equity value is smaller than subsidiary equity value. The excess returns in this region are more positive and volatile, with median and mean values of 1.57\% and 17.02\%, and Q1 and Q3 quartile values of $-1.07 \%$ and $30.80 \%$.

- Place Table V about here -

To understand the greater volatility of returns in the second region, consider the highest return of 114.95\%, which occurs in the subsidiary SEO by General Defense Corp. announced on January 7, 1981. Clabir Corp., the parent, owned 65\% of the subsidiary. The parent and subsidiary equities had respective market values of $\$ 58.863$ and $\$ 84.000$ million on $A D$-2, and their excess returns equaled $-3.439 \%$ and $-12.684 \%$. From this, I calculate the nonsubsidiary equity value as $\$(58.863-0.65 \times 84.000)=\$ 4.263$ million, and the nonsubsidiary equity return as $(-3.439 \times 58.863+0.65 \times 12.684 \times 84.000) / 4.263=114.95 \%$. The large return is the result of small nonsubsidiary equity value calculated by ignoring debt.

The last row of Panel A shows that for the combined sample of 78 subsidiary SEOs the Q1, median, and Q3 values of $-2.39 \%, 0.13 \%$, and 3.78\%. The mean three-day excess return for my sample equals 3.62\%, which when compared with the median value of $0.13 \%$ and percent positive value of 51 , indicates the strong influence of outliers. Panel B shows that the two-day excess returns have Q1, median, and Q3 values of $-2.00 \%, 0.76 \%$, and 3.99\%, and a mean value of 2.93\%. 
At first glance, it may appear that the above two-day excess return is bordering on significant, with one out of three $p$-values below 10\%. To further examine the significance of this result, Figure 1 plots the mean three-day and two-day implied excess returns of the nonsubsidiary equity value of parent firms within decile portfolios formed by the subsidiary equity value divided by total equity value for the sample of 78 subsidiary SEOs. Notice that this procedure relies on ex-ante information. The lower eight deciles span the first region described in Panels A and B, and the upper two deciles span the second region. This figure shows that any evidence of positive implied excess returns is driven by the top decile. The three-day and two-day excess returns in this decile have mean values of $36.88 \%$ and $27.08 \%$. The ratio of subsidiary equity value to total equity value has a mean value of 0.84 . For the hypothetical parent firm with equity and debt values of $\$ 100$ each, the distortions induced by ignoring unobservable debt returns would be particularly acute when the parent owns a corresponding \$84 equity stake in the subsidiary.

- Place Figure 1 about here -

More importantly, if the strategic financing hypothesis explains subsidiary SEOs, then I argue that the evidence should show up in a large subset of data formed by reasonable ex-ante criteria, such as the first nine deciles in Figure 1. In this region, the median, mean, and percent positive values of threeday implied excess returns to nonsubsidiary equity value equal $-0.55 \%, 0.34 \%$, and 46 . The two-day excess returns have corresponding values of $0.48 \%, 0.55 \%$, and 55 . All tests of median, mean, and percent positive are insignificant, with $p$-values between 0.38 and 0.66 , and two measures are negative. Looking across the range, implied excess returns within the first five deciles tend to be positive, while those within the next four deciles tend to be negative. Finally, even with the inclusion of the top decile, the robust statistics of median and percent positive values remain insignificant. (The mean is an unreliable statistic as the associated $t$-statistic assumes a normal distribution of excess returns. $)^{9}$

A fair assessment of the evidence in Table $\mathrm{V}$ and Figure 1 is that the implied excess returns to the nonsubsidiary equity value of parent firms in subsidiary SEOs are insignificant. Given the assumptions involved in calculating implied returns, I argue further that one should pay attention to direct tests, such 
as the observed nonissuing firm returns, which are insignificant for both parent and subsidiary SEOs. In particular, the counterpart of the nonsubsidiary equity return in a subsidiary SEO is the subsidiary equity return in a parent SEO, which is directly observed, making it a credible test of strategic financing hypothesis. As shown in Table III, this measure is insignificant. Finally, Panels C and D of Table V show that the implied excess returns to nonsubsidiary equity value of parent firms in parent SEOs are significantly negative, which is not surprising.

\section{Motives for Parent Primary, Subsidiary Secondary, and Subsidiary Primary Issues}

I now analyze the motives for different types of equity issues within a parent-subsidiary structure. The strategic financing hypothesis predicts that this choice is guided only by the relative valuation of the two stocks. It predicts no role for the financing needs of the issuer as the proceeds can be transferred across units. The alternative hypothesis posits that equity issues within a parent-subsidiary structure are similar to equity issues by stand-alone firms modeled by Myers and Majluf. In this framework, firms issue stock when they need funds and when their stock is overpriced. In addition, stock sales by a parent firm in a subsidiary secondary issue may represent the parent's desire to divest its subsidiary holdings.

I measure the potential undervaluation or overvaluation of the parent and subsidiary stocks by their prior-year excess returns reported in Table III. This is a common interpretation in the literature, although prior returns can also be interpreted as a measure of emerging growth opportunities. Unfortunately, an unambiguous measure of potential overvaluation that is not correlated with growth opportunities is not obvious. I next measure financing need by using the financing deficit variable employed by Frank and Goyal (2003) as follows:

$$
\text { Deficit }=\text { Dividends + Investments + Change in working capital - Internal cash flow. }
$$

I use Frank and Goyal's detailed computation procedure for the right-hand side variables. ${ }^{10}$ I normalize the deficit by total assets, and average it over a two-year period ending with the fiscal year of equity issue.

The required returns and accounting data for both the parent and subsidiary firms are available for 20 parent primary, 25 subsidiary secondary, and 32 subsidiary primary issues. Mixed issues are excluded. 
Table VI shows the results of a multinomial probit model that relates the pair-wise choice between issue types to measures of overvaluation and financing need. Column (1) shows the choice between a subsidiary secondary and a parent primary issue. Higher parent prior returns and parent annual deficits both significantly increase the probability of choosing a parent primary issue. A subsidiary secondary issue is less likely to be used to meet the financing needs of the parent, perhaps due to the smaller subsidiary size in most cases. Surprisingly, a higher subsidiary prior return does not significantly increase the probability of choosing a subsidiary secondary issue. However, subsidiary deficit has no significant effect on the choice between a parent primary and a subsidiary secondary issue, as in both cases the proceeds go to the parent firm.

- Place Table VI about here -

Column (2) shows the choice between a subsidiary primary and a parent primary issue. In this case, the proceeds go to different firms. All four independent variables are significant. Higher parent prior returns and parent annual deficits significantly increase the probability of choosing a parent primary issue, and higher subsidiary prior returns and subsidiary annual deficits significantly increase the probability of choosing a subsidiary primary issue. This column shows that primary issues by either firm are significantly related to its own overvaluation and its own financing need.

Column (3) shows the choice between a subsidiary primary and a subsidiary secondary issue. Three of the four independent variables are now insignificant, and one is significant in the opposite direction, as a higher parent annual deficit significantly increases the probability of choosing a subsidiary primary issue. This result is inconsistent with the strategic financing hypothesis, which predicts the insignificance of both annual deficits, and also the alternative hypothesis, which predicts a significantly positive coefficient of subsidiary deficit and a significantly negative coefficient of parent deficit. This may be due to a missing variable, a possibility that I investigate below.

Panel B of Table VI reports the mean and median values of parent and subsidiary prior returns and annual deficits for different issue types. Notice subsidiary deficits are higher than parent deficits for all three issue types. This is consistent with a general belief that carve-out subsidiaries are growth firms 
that need capital. In addition, while the prior returns for issuing firms are stronger, the prior returns of nonissuing firms are generally positive (except the median return in the case of subsidiary secondary issues).

Comparing across issue types, parent primary issues occur when the parent prior returns are highest, while subsidiary primary issues occur when the subsidiary prior returns are highest. Further, parent primary issues occur when the parent deficit is highest, and subsidiary primary issues occur when the subsidiary deficit is highest. So far, then, the evidence confirms that potential overvaluation of a firm's own stock and its own financing need are significant determinants of primary issues. However, the subsidiary secondary issues break this trend. On average, these issues occur when the parent annual deficit is negative (i.e., a surplus) and the subsidiary deficit is smaller than with the other issue types. Note further that the two firms have different 2-digit standard industrial classification (SIC) codes in $87 \%$ of subsidiary secondary issues and $69 \%$ of parent primary issues, which suggests divestiture motives in the former case. I next divide the sample of 25 subsidiary secondary issues into 13 cases for which divestiture motives are given in media reports and 12 cases for which such motives are not given. Both prior returns are lower in the first case, and the parent deficit is even more negative in the first case and slightly positive in the second case. This suggests that divestiture motives are an independent factor in equity issues, and that parent firms wanting to divest a subsidiary stake are less concerned about overvaluation and financing needs.

Finally, I report a binomial probit analysis of the choice between a subsidiary primary issue and a subsidiary secondary issue by excluding cases for which divestiture motives are given. Column (4) in Panel A shows that the anomalous result of Column (3) disappears. The parent annual deficit becomes insignificant, and the $t$-statistic of subsidiary annual deficit becomes larger (although it remains insignificant). Overall, although not uniformly significant, the evidence suggests that the overvaluation of issued stock, the financing needs of the issuing firm, and divestiture motives are all determinants of equity issues in a parent-subsidiary structure. Recall that the strategic financing hypothesis predicts no role for the differential financing needs of issuing and nonissuing firms or divestiture motives such as a lack of synergy between their businesses. 


\section{Conclusions}

Can equity offerings to outside investors increase firm value by revealing new information about existing firm assets? A positive response to this question would be interesting and important, as it would mean that under certain structures or circumstances firms are not afraid to seek equity financing, and may even be eager to do so. In the context of a publicly traded parent-subsidiary structure, Slovin and Sushka (1997) present supporting evidence with a sample of 38 subsidiary and 37 parent SEOs during 1975 to 1993. They find that issuing firms earn significantly negative excess returns and nonissuing firms earn significantly positive excess returns in both cases. They also find positive excess returns to nonsubsidiary assets of parent firms and wealth gains to the combined parent-subsidiary structure in subsidiary SEOs. They interpret their evidence as inconsistent with the simple adverse selection hypothesis of Myers and Majluf (1984) and consistent with the strategic financing hypothesis of Nanda (1991).

I present a different perspective on these issues with a more recent sample of 90 subsidiary and 37 parent SEOs that occur during 1981 to 2002 within parent-subsidiary structures established after an equity carve-out or a partial acquisition. For both parent and subsidiary SEOs, I find that issuing firms earn significantly negative announcement-period excess returns, but nonissuing firms earn insignificant excess returns. I also find insignificant implied excess returns to the nonsubsidiary equity value of parent firms in subsidiary SEOs (with the possible exception of firms in the top one decile, for which the ex-ante implied nonsubsidiary equity value is very small, likely a result of ignoring debt value and unobservable debt returns). I find further that the combined excess returns to public shareholders of the two firms are insignificant in subsidiary SEOs and significantly negative in parent SEOs. My evidence suggests that the market reaction to SEOs within parent-subsidiary structures is similar to the market reaction to SEOs by stand-alone firms outside such structures. In both cases the net result is a downward revision in the issuing firm's value. I find that neither subsidiary SEOs nor parent SEOs increase the combined value of the parent-subsidiary structure.

My results suggest that the strategic financing hypothesis of Nanda does not explain the market reaction to equity issues within publicly traded parent-subsidiary structures, possibly due to the difficulty 
of transferring proceeds within such structures. Only five subsidiary firms mention debt repayment to the parent firm as a motive for equity issuance, and only one parent mentions using proceeds for subsidiary purposes. Finally, I analyze the motives underlying different types of equity issues. A multinomial probit model shows that the choice among a parent primary, a subsidiary primary, and a subsidiary secondary issue is guided by the financing needs of the issuing firm, in addition to potential overvaluation of the issued stock and divestiture motives. Overall, although there may be individual cases in which a publicly traded parent-subsidiary structure enhances financing flexibility, I conclude that this is not descriptive of the aggregate sample of seasoned equity offerings within such structures analyzed in this paper. 


\section{References}

Bayless, Mark, and Susan Chaplinsky, 1996, Is there a window of opportunity for seasoned equity issuance?, Journal of Finance 51, 253-278.

Billett, Matthew T., and Jon A. Garfinkel, 2004, Financial flexibility and the cost of external finance for U.S. bank holding companies, Journal of Money, Credit, and Banking 36, 827-852.

Black’s Law Dictionary, 1999, Seventh edition (West Group, St. Paul, Minnesota).

Frank, Murray Z., and Vidhan K. Goyal, 2003, Testing the pecking order theory of capital structure, Journal of Financial Economics 67, 217-248.

Karpoff, Jonathan M., 1987, The relation between price changes and trading volume: A survey, Journal of Financial and Quantitative Analysis 22, 109-126.

Lamont, Owen A., and Richard H. Thaler, 2003, Can the market add and subtract? Mispricing in tech stock carve-outs, Journal of Political Economy 111, 227-268.

Loughran, Tim, and Jay R. Ritter, 1995, The new issues puzzle, Journal of Finance 50, 23-51.

Mitchell, Mark, Todd Pulvino, and Erik Stafford, 2002, Limited arbitrage in equity markets, Journal of Finance 57, 551-584.

Morck, Randall, Andrei Shleifer, and Robert W. Vishny, 1988, Management ownership and market valuation: An empirical analysis, Journal of Financial Economics 20, 293-315.

Myers, Stewart C., and Nicholas S. Majluf, 1984, Corporate financing and investment decisions when firms have information that investors do not have, Journal of Financial Economics 13, 187-221.

Nanda, Vikram, 1991, On the good news in equity carveouts, Journal of Finance 46, 1717-1737.

Schill, Michael J., and Chunsheng S. Zhou, 2001, Pricing an emerging industry: Evidence from internet subsidiary carve-outs, Financial Management 30, 5-33.

Slovin, Myron B., and Marie E. Sushka, 1997, The implications of equity issuance decisions within a parent-subsidiary governance structure, Journal of Finance 52, 841-857.

Vijh, Anand M., 2002, The positive announcement-period returns of equity carveouts: Asymmetric information or divestiture gains?, Journal of Business 75, 153-190.

Weston, J., 1979, The tender takeover, Mergers and Acquisitions 14, 74-82. 


\section{Footnotes}

1. The Black’s Law Dictionary (1999) gives the following definitions. Subsidiary corporation: A corporation in which a parent corporation has a controlling share. Controlling interest: Sufficient ownership of stock in a company to control policy and management; esp., a greater-than-50\% ownership interest in an enterprise. Affiliate: A corporation that is related to another corporation by shareholdings or other means of control; a subsidiary, parent, or sibling corporation. Other internet dictionaries define a subsidiary as a company for which a majority of the voting stock is owned by a holding company, while an affiliate is a company in which another company has a minority interest. As discussed later, my sample includes cases such that one firm owns at least $25 \%$ of the equity of another firm. Strictly speaking, I should use the term "parent-subsidiary structure" when ownership exceeds 50\% and the term "affiliatedfirm structure” when ownership is less than 50\%. However, the economics of the problem analyzed in this paper are similar between these two cases. For expositional reasons, I therefore use the term "parentsubsidiary structure” to describe my entire sample.

2. In other contexts, financing flexibility has been shown to increase firm value. For example, Billett and Garfinkel (2004) show that banks with lower costs of accessing both insured and uninsured deposit markets have higher market value.

3. The sample of carve-outs includes 336 cases during 1980 to 1997 from Vijh (2002). The sample of partial acquisitions excludes cases in which the acquirer owns less than $25 \%$ or greater than $90 \%$ of the subsidiary’s stock on acquisition completion date. A known second event date is a date when the parentsubsidiary structure is ended by a spinoff, a third-party sale, or a parent reacquisition of the subsidiary firm as identified by Vijh (2002).

4. My choice of $80 \%$ rather than $100 \%$ as a cut-off is motivated by two considerations. First, it is not clear that an $80 \%$ secondary and a $100 \%$ secondary are particularly different from an economic 
standpoint. Second, sometimes an issue is intended to be all secondary, but the firm offers some primary shares to cover the overallotment option. I prefer to treat such cases as secondary issues rather than mixed issues.

5. As further anecdotal evidence, consider Infinity Broadcasting Corp., which acquired a 25\% stake in Westwood One Inc. in 1994. Infinity received all management rights, and thus was frequently mentioned as controlling Westwood.

6. For example, the largest subsidiary excess return in the sample of 37 parent SEOs is $39.24 \%$. If it is present in a subset of 18 issues, as in the second-to-last row of Panel B, it contributes $2.18 \%$ to the mean return. Without this observation, even the three-day mean excess return for all parent SEOs in Table III would equal $-0.51 \%$. Examination of media reports suggests that this return is not related to the parent SEO announcement.

7. Using two-day returns yields similar results that are available from the author on request.

8. I verify that the parent firms in such cases are real operating companies with real sales and real earnings. As these are not shell companies or companies facing litigation awards leading to negative equity, on economic grounds they should be included in other tests. Unfortunately, given the nonobservability of debt returns and the cross-holding of debt between parent and subsidiary, there is no obvious method of calculating nonsubsidiary equity returns for such cases. As a robustness check, I verify that my results in the other tests are qualitatively similar with or without the exclusion of these 12 cases.

9. I report a final test based on a comparison of the observed excess return to the parent stock and the calculated excess return by assuming that the nonsubsidiary equity return is zero. Not surprisingly, the evidence is similar to that for nonsubsidiary equity returns in Table V. For all ten deciles, the mean and median difference between three-day excess returns equal $0.86 \%$ and $0.09 \%$ ( $p$-values 0.16 and 0.71 ). 
Excluding the top decile changes these values to $0.47 \%$ and $-0.37 \%$ ( $p$-values 0.45 and 0.64 ). Using twoday returns gives mean and median values of $0.87 \%$ and $0.60 \%$ ( $p$-values 0.09 and 0.14 ) for all ten deciles, and $0.65 \%$ and $0.46 \%$ ( $p$-values 0.22 and 0.35 ) for the first nine deciles. Notice that this test, like others in this section, suffers from limitations imposed by unobservable debt returns.

10. Their procedure is described as follows. Dividends are always defined by Compustat Annual Data Item 127. For firms reporting format codes 1 to 3, investments equal Item 128 + Item 113 + Item 129 + Item 219 - Item 107 - Item 109. For firms reporting format code 7, investments equal Item 128 + Item 113 + Item 129 - Item 107 - Item 109 - Item 309 - Item 310. For firms reporting code 1, change in working capital equals Item 236 + Item 274 + Item 301. For firms reporting format codes 2 and 3, change in working capital equals - Item 236 + Item 274 - Item 301. For firms reporting format code 7, change in working capital equals - Item 302 - Item 303 - Item 304 - Item 305 - Item 307 + Item 274 - Item 312 Item 301. For firms reporting format codes 1 to 3, internal cash flow equals Item 123 + Item 124 + Item 125 + Item 126 + Item 106 + Item 213 + Item 217 + Item 218. For firms reporting format code 7, internal cash flow equals Item 123 + Item 124 + Item 125 + Item 126 + Item 106 + Item 213 + Item 217 + Item 314. The following variables are recorded as zero if missing or combined with other data items: Item 127, Item 128, Item 113, Item 129, Item 219, Item 107, Item 109, Item 309, Item 310, Item 236, Item 301, Item 302, Item 303, Item 304, Item 305, Item 307, Item 312, Item 124, Item 125, Item 126, Item 106 , Item 213, Item 217, Item 218, and Item 314. The normalizing variable total assets is given by Item 6. 
Table I

\section{Sample Distribution over Time and Summary Statistics}

The sample includes all seasoned equity offerings (SEOs) made within a publicly traded parent-subsidiary structure over the period 1981-2002 that could be obtained from the SDC new issues database. The parent-subsidiary structures are established by an earlier equity carve-out or a partial acquisition. I impose the following additional criteria: 1. Returns data for both the parent and subsidiary firms are available from the CRSP files, and ownership data before announcement are available from media reports or SEC filings. 2. The parent holds at least $25 \%$ of the outstanding subsidiary stock. 3 . The market value of outstanding subsidiary stock is not less than $5 \%$ of the market value of the outstanding parent stock. 4. Both the parent and subsidiary stocks are priced at more than $\$ 3$. Additional data used in this table are obtained from the following sources. The market values are calculated as of two days before the announcement date of the SEO. The announcement date is the earlier of the first media report and the SEC filing date. Book value is calculated as of the last fiscal year-end before the first announcement date. Proceeds size and the proportion of primary vs. secondary shares are obtained from SDC. A subsidiary primary issue is one in which at least $80 \%$ of all proceeds consist of newly issued shares, and a subsidiary secondary issue is one in which at least $80 \%$ of all proceeds are existing shares held by the parent firm.

Panel A: Sample distribution over time

\begin{tabular}{lccccc}
\hline Year & $1981-1985$ & $1986-1990$ & $1991-1995$ & $1996-2002$ & All years \\
\hline Number of subsidiary SEOs & 13 & 9 & 37 & 31 & 90 \\
Number of parent SEOs & 7 & 6 & 12 & 12 & 37 \\
All SEOs & 20 & 15 & 49 & 43 & 127 \\
Number of structures established by an & & & & & 106 \\
equity carve-out & & & & & 21 \\
Number of structures established by a & & & & & \\
partial acquisition & & & & & \\
\hline
\end{tabular}

Panel B: Summary statistics

\begin{tabular}{|c|c|c|c|c|}
\hline \multirow[t]{2}{*}{ Description } & \multicolumn{2}{|c|}{ Subsidiary SEOs } & \multicolumn{2}{|c|}{ Parent SEOs } \\
\hline & Mean & Median & Mean & Median \\
\hline Market value of issuing firm in \$million & 860 & 406 & 5008 & 1557 \\
\hline Market value of nonissuing firm & 2877 & 1178 & 742 & 344 \\
\hline Ratio of subsidiary to parent market value & 0.82 & 0.44 & 0.47 & 0.23 \\
\hline Ratio of subsidiary stake to parent market value & 0.45 & 0.25 & 0.26 & 0.12 \\
\hline Ownership of subsidiary by parent before SEO & 57 & 55 & 58 & 56 \\
\hline Number of cases ownership exceeds $50 \%$ & 56 & & 24 & \\
\hline Number of cases ownership between $25 \%$ and $50 \%$ & 34 & & 13 & \\
\hline Proceeds size in \$million & 177 & 67 & 336 & 124 \\
\hline Proceeds size as a proportion of issuing firm size & 0.25 & 0.19 & 0.16 & 0.11 \\
\hline Primary issues & 42 & & 34 & \\
\hline Mixed issues & 16 & & 3 & \\
\hline Secondary issues & 32 & & & \\
\hline Book-to-market value of issuing firm & 0.389 & 0.292 & 0.504 & 0.470 \\
\hline Book-to-market value of nonissuing firm & 0.581 & 0.436 & 0.465 & 0.431 \\
\hline Subsidiary age as a publicly traded firm in years & 3.25 & 1.88 & 6.16 & 1.92 \\
\hline
\end{tabular}


Table II

\section{Stated Uses of Seasoned Equity Offering (SEO) Proceeds}

The sample of 90 subsidiary and 37 parent SEOs made within a parent-subsidiary structure is described in Table I. In each case, I examine the media reports related to the SEO. This table summarizes the intended uses of the SEO proceeds according to the firm's management. A subsidiary primary issue is one in which at least $80 \%$ of all proceeds consist of newly issued shares, and a subsidiary secondary issue is one in which at least $80 \%$ of all proceeds are existing shares held by the parent firm.

\begin{tabular}{lccccc}
\hline & \multicolumn{3}{c}{ Subsidiary SEOs } & Parent \\
\cline { 2 - 5 } Description & All & Primary & Secondary & Mixed & SEOs \\
\hline Number for which intended use of proceeds is given & 74 & 31 & 28 & 15 & 28 \\
Intended uses of SEO proceeds: & & & & & \\
1. Reduce debt & 28 & 18 & 6 & 4 & 18 \\
2. Reduce debt owed to affiliate or issue new debt & 5 & 4 & 0 & 1 & 1 \\
3. Divestiture reasons & 20 & - & 16 & 4 & - \\
4. General corporate purposes, incl. working capital & 32 & 20 & 5 & 7 & 20 \\
5. Investments, including upgrades and acquisitions & 32 & 17 & 7 & 8 & 16 \\
6. Miscellaneous & 2 & 0 & 2 & 0 & 2 \\
\hline
\end{tabular}


Table III

Pre-Announcement and Announcement Excess Returns and Trading Volume

The sample of 90 subsidiary and 37 parent seasoned equity offerings (SEOs) made within a parent-subsidiary structure is described in Table I. The announcement date is denoted by $A D$, and it is the earlier of the first media report date and the SEC filing date. Excess returns are calculated by subtracting the holding-period returns for the value-weighted market portfolio from the holding-period returns for the parent or subsidiary stock. The combined excess return is calculated by weighting the parent excess return by the market value of parent stock and the subsidiary excess return by the market value of subsidiary stock held by outside shareholders (i.e., excluding the parent ownership). The holding period includes 250 days from $A D-251$ to $A D-2$ for calculating the preannouncement returns, and three days from $A D-1$ to $A D+1$ for calculating the announcement returns. The meanadjusted excess trading volume is calculated as the three-day announcement-period trading volume divided by the average three-day trading volume over $A D-160$ to $A D-40$, minus one. All excess returns and trading volumes are reported in percent form. The $t$-statistics and $z$-statistics are calculated from the cross-sectional distribution of excess returns or excess trading volumes. The notation ${ }^{*},{ }^{* *}$, and ${ }^{* * *}$ denotes statistical significance at the $10 \%, 5 \%$, and $1 \%$ levels.

Panel A: 90 Subsidiary SEOs

\begin{tabular}{|c|c|c|c|c|c|c|}
\hline \multirow[b]{2}{*}{ Description } & \multicolumn{2}{|c|}{ Subsidiaries } & \multicolumn{2}{|c|}{ Parents } & \multicolumn{2}{|c|}{ Combined } \\
\hline & $\begin{array}{l}\text { Mean } \\
(t \text {-stat })\end{array}$ & $\begin{array}{c}\text { Median } \\
(z \text {-stat) }\end{array}$ & $\begin{array}{l}\text { Mean } \\
(t \text {-stat })\end{array}$ & $\begin{array}{c}\text { Median } \\
(z \text {-stat })\end{array}$ & $\begin{array}{l}\text { Mean } \\
(t \text {-stat })\end{array}$ & $\begin{array}{l}\text { Median } \\
\text { (z-stat) }\end{array}$ \\
\hline $\begin{array}{l}\text { Excess return over } \\
A D-251 \text { to } A D-2\end{array}$ & $\begin{array}{l}62.79 \\
(5.17)^{* * *}\end{array}$ & $\begin{array}{l}35.73 \\
(4.43)^{* * *}\end{array}$ & $\begin{array}{l}24.03 \\
(3.73)^{* * *}\end{array}$ & $\begin{array}{c}5.06 \\
(1.05)\end{array}$ & & \\
\hline $\begin{array}{l}\text { Excess return over } \\
A D-1 \text { to } A D+1\end{array}$ & $\begin{array}{l}-2.01 \\
(-3.01)^{* * *}\end{array}$ & $\begin{array}{l}-1.73 \\
(-2.74)^{* * *}\end{array}$ & $\begin{array}{c}0.27 \\
(0.52)\end{array}$ & $\begin{array}{l}-0.13 \\
(-0.21)\end{array}$ & $\begin{array}{l}-0.11 \\
(-0.20)\end{array}$ & $\begin{array}{l}-0.37 \\
(-1.48)\end{array}$ \\
\hline $\begin{array}{l}\text { Excess return over } \\
A D \text { to } A D+1\end{array}$ & $\begin{array}{l}-1.99 \\
(-3.06)^{* * *}\end{array}$ & $\begin{array}{l}-1.62 \\
(-3.37)^{* * *}\end{array}$ & $\begin{array}{c}0.46 \\
(1.03)\end{array}$ & $\begin{array}{c}0.08 \\
(0.21)\end{array}$ & $\begin{array}{c}0.10 \\
(0.22)\end{array}$ & $\begin{array}{l}-0.26 \\
(-0.84)\end{array}$ \\
\hline $\begin{array}{l}\text { Excess trading volume over } \\
A D-1 \text { to } A D+1\end{array}$ & $\begin{array}{l}27.45 \\
(2.16)^{* *}\end{array}$ & & $\begin{array}{c}6.52 \\
(0.66)\end{array}$ & & & \\
\hline
\end{tabular}

Panel B: 37 Parent SEOs

\begin{tabular}{|c|c|c|c|c|c|c|}
\hline \multirow[b]{2}{*}{$\begin{array}{l}\text { Excess return over } \\
A D-251 \text { to } A D-2\end{array}$} & \multicolumn{2}{|c|}{ Parents } & \multicolumn{2}{|c|}{ Subsidiaries } & \multicolumn{2}{|c|}{ Combined } \\
\hline & $\begin{array}{l}42.63 \\
(3.29)^{* * *}\end{array}$ & $\begin{array}{l}13.45 \\
(1.81)^{*}\end{array}$ & $\begin{array}{l}25.95 \\
(1.89)^{*}\end{array}$ & $\begin{array}{c}3.83 \\
(1.48)\end{array}$ & & \\
\hline $\begin{array}{l}\text { Excess return over } \\
A D-1 \text { to } A D+1\end{array}$ & $\begin{array}{l}-2.20 \\
(-2.76)^{* * *}\end{array}$ & $\begin{array}{l}-1.55 \\
(-1.81)^{*}\end{array}$ & $\begin{array}{c}0.56 \\
(0.44)\end{array}$ & $\begin{array}{c}-0.73 \\
(-1.48)\end{array}$ & $\begin{array}{l}-1.92 \\
(-2.56)^{* *}\end{array}$ & $\begin{array}{c}-1.37 \\
(-1.48)\end{array}$ \\
\hline $\begin{array}{l}\text { Excess return over } \\
A D \text { to } A D+1\end{array}$ & $\begin{array}{l}-1.89 \\
(-2.86)^{* * *}\end{array}$ & $\begin{array}{l}-1.71 \\
(-1.81)^{*}\end{array}$ & $\begin{array}{c}0.59 \\
(0.56)\end{array}$ & $\begin{array}{c}0.25 \\
(0.49)\end{array}$ & $\begin{array}{l}-1.68 \\
(-2.63)^{* *}\end{array}$ & $\begin{array}{c}-1.39 \\
(-1.81)^{*}\end{array}$ \\
\hline $\begin{array}{l}\text { Excess trading volume over } \\
A D-1 \text { to } A D+1\end{array}$ & $\begin{array}{l}85.06 \\
(2.64)^{* *}\end{array}$ & & $\begin{array}{l}18.62 \\
(0.99)\end{array}$ & & & \\
\hline
\end{tabular}


Table IV

\section{Cross-Sectional Differences in Announcement Excess Returns}

The sample of 90 subsidiary and 37 parent seasoned equity offerings (SEOs) made within a parent-subsidiary structure is described in Table I. This table compares the market-adjusted announcement excess returns over a three-day period, from $A D-1$ to $A D+1$, across subsets of data. Market-adjusted excess returns are calculated by subtracting the holding-period returns for the value-weighted market portfolio from the holding-period returns for the issuing or nonissuing stock. The combined excess return is calculated by adding the parent excess return weighted by the market value of parent stock and the subsidiary excess return weighted by the market value of subsidiary stock held by outside shareholders (i.e., excluding the parent ownership). Subsets of data are formed by parent ownership, type of issue, whether the parent receives some of the proceeds, whether the subsidiary stake value is less than or greater than the parent equity value (see Section II.D and Table V), and whether the ratio of subsidiary stake value to parent equity value is below or above median. The data on parent ownership comes from media reports and SEC filings. Primary issues include cases in which at least $80 \%$ of shares issued are new shares, and secondary issues include cases in which at least $80 \%$ of shares issued are old shares held by the parent firm. The 50 cases in which the parent receives some of the proceeds in subsidiary SEOs include 46 cases of secondary or mixed issues (excluding cases of mixed issues in which sellers were identified as other than parent) and four cases of primary issues in which the stated purpose is to repay parent debt. The size ratio is based on stock prices as of two days before the announcement of the SEO. The $t$-statistics and $z$-statistics are calculated from the cross-sectional distribution of excess returns or excess trading volumes. The notation ${ }^{*}$, ${ }^{* *}$, and ${ }^{* * *}$ denotes statistical significance at the $10 \%, 5 \%$, and $1 \%$ levels.

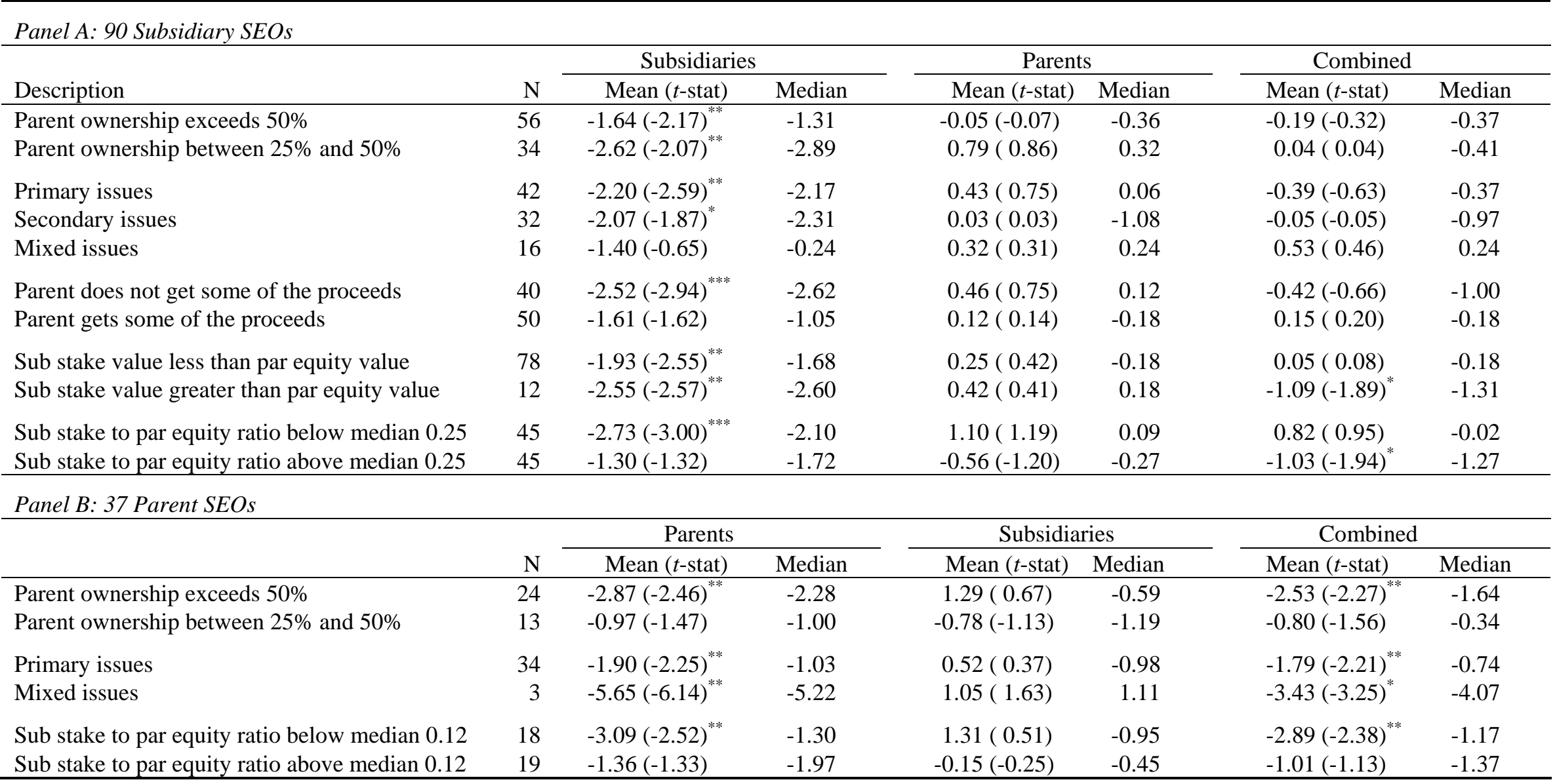


Table V

\section{Implied Excess Returns to Nonsubsidiary Equity Value of Parent Firms}

The initial sample of 90 subsidiary and 37 parent seasoned equity offerings (SEOs) made within a parent-subsidiary structure is described in Table I. The final sample used in this table excludes cases in which the implied nonsubsidiary equity value of the parent firm using the following procedure is negative. In this procedure, $M V$ and $X R E T$ denote the market value and the market-adjusted excess return and $\alpha$ denotes the fractional ownership of subsidiary equity (or stock) by parent. The subscripts par equity and sub equity refer to the observed market value of all outstanding equity of parent and subsidiary firms, and the subscripts par sub equity and par nonsub equity refer to the implied market value of subsidiary and nonsubsidiary parts of the total equity of parent firm. Ignoring the role of debt, these quantities are calculated as

$$
M V_{\text {par sub equity }}=\alpha \times M V_{\text {subequity }}, \quad M V_{\text {par nonsub equity }}=M V_{\text {par equity }}-M V_{\text {par subequity }} .
$$

I next calculate the implied excess returns to nonsubsidiary equity value of the parent firm as

$$
X R E T_{\text {par nonsub equity }}=\left(X R E T_{\text {par equity }} \times M V_{\text {par equity }}-X R E T_{\text {subequity }} \times M V_{\text {par sub equity }}\right) / M V_{\text {par nonsub equity }} .
$$

All market values are based on $A D-2$ prices. Q1 and Q3 refer to the $25^{\text {th }}$ and $75^{\text {th }}$ percentile of the return distribution. The figures in parentheses next to the median, mean, and percent positive values represent the $p$-values based on the Wilcoxon signed rank test, the Student's $t$-test, and the binomial test. All statistics are calculated from the crosssectional distribution of excess returns. The notation ${ }^{*},{ }^{* *}$, and ${ }^{* * *}$ denotes statistical significance at the $10 \%, 5 \%$, and

\begin{tabular}{|c|c|c|c|c|c|c|}
\hline \multirow[b]{2}{*}{$\begin{array}{l}\text { Relation between nonsubsidiary } \\
\text { equity value and subsidiary } \\
\text { equity value of parent firm }\end{array}$} & \multicolumn{6}{|c|}{$\begin{array}{l}\text { Implied excess returns to nonsubsidiary equity value of parent firms } \\
\qquad\left(X R E T_{\text {par nonsub equity }}\right)\end{array}$} \\
\hline & $\mathrm{N}$ & Q1 & $\begin{array}{c}\text { Median } \\
\text { (Wilcoxon } \\
\text { signed rank } \\
p \text {-value) }\end{array}$ & Q3 & $\begin{array}{c}\text { Mean } \\
\text { (Student's } \\
t \text {-test based } \\
p \text {-value) } \\
\end{array}$ & $\begin{array}{c}\text { Percent } \\
\text { positive } \\
\text { (binomial test } \\
\text { based } p \text {-value) } \\
\end{array}$ \\
\hline \multicolumn{7}{|c|}{ Panel A: 78 Subsidiary SEOs, three-day returns } \\
\hline$M V_{\text {par nonsub equity }}>M V_{\text {par sub equity }}$ & 63 & -3.23 & $-0.55(0.72)$ & 2.74 & $0.43(0.61)$ & $0.44(0.61)$ \\
\hline$M V_{\text {par nonsub equity }}<M V_{\text {par sub equity }}$ & 15 & -1.07 & $1.57(0.06)^{*}$ & 30.80 & $17.02(0.06)^{*}$ & $0.73(0.12)$ \\
\hline Combined sample & 78 & -2.39 & $0.13(0.51)$ & 3.78 & $3.62(0.06)^{*}$ & $0.51(0.91)$ \\
\hline \multicolumn{7}{|c|}{ Panel B: 78 subsidiary SEOs, two-day returns } \\
\hline$M V_{\text {par nonsub equity }}>M V_{\text {par sub equity }}$ & 63 & -2.00 & $0.26(0.45)$ & 2.75 & $0.61(0.37)$ & $0.56(0.61)$ \\
\hline$M V_{\text {par nonsub equity }}<M V_{\text {par sub equity }}$ & 15 & -12.27 & $9.11(0.19)$ & 27.47 & $12.69(0.10)^{*}$ & $0.73(0.12)$ \\
\hline Combined sample & 78 & -2.00 & $0.76(0.12)$ & 3.99 & $2.93(0.06)^{*}$ & $0.58(0.21)$ \\
\hline \multicolumn{7}{|c|}{ Panel C: 36 parent SEOs, three-day returns } \\
\hline$M V_{\text {par nonsub equity }}>M V_{\text {par sub equity }}$ & 33 & -4.74 & $-1.87(0.00)^{* * *}$ & 0.46 & $-2.66(0.01)^{* * *}$ & $0.30(0.04)^{* *}$ \\
\hline$M V_{\text {par nonsub equity }}<M V_{\text {par sub equity }}$ & 3 & -16.70 & $-5.27(0.75)$ & 16.46 & $-1.84(0.87)$ & $0.33(1.00)$ \\
\hline Combined sample & 36 & -5.45 & $-1.89(0.00)^{* * *}$ & 0.47 & $-2.59(0.03)^{* *}$ & $0.31(0.03)^{* *}$ \\
\hline \multicolumn{7}{|c|}{ Panel D: 36 parent SEOs, two-day returns } \\
\hline$M V_{\text {par nonsub equity }}>M V_{\text {par sub equity }}$ & 33 & -4.27 & $-1.66(0.01)^{* * *}$ & 0.82 & $-2.08(0.01)^{* * *}$ & $0.39(0.30)$ \\
\hline$M V_{\text {par nonsub equity }}<M V_{\text {par sub equity }}$ & 3 & -12.32 & $-3.15(0.25)$ & -2.18 & $-5.89(0.21)$ & $0.00(0.25)$ \\
\hline Combined sample & 36 & -4.28 & $-1.96(0.00)^{* * *}$ & 0.79 & $-2.40(0.00)^{* * *}$ & $0.36(0.13)$ \\
\hline
\end{tabular}
$1 \%$ levels. 
Table VI

\section{Probit Models Relating Issue Type to Measures of Overpricing, Financing Deficit, and Divestiture Motives}

The initial sample of 90 subsidiary and 37 parent seasoned equity offerings (SEOs) made within a parent-subsidiary structure is described in Table I. However, the final sample includes 20 parent primary $(P P), 25$ subsidiary secondary (SS), and 32 subsidiary primary $(S P)$ issues for which data can be found for measures of overpricing and financing deficits of both the parent and subsidiary firms. I exclude subsidiary SEOs that are neither mainly primary (i.e., at least $80 \%$ of the shares issued are new) nor mainly secondary (i.e., at least $80 \%$ of the shares issued are subsidiary shares held by the parent). I also exclude parent SEOs that are not mainly primary. Overpricing is measured by market-adjusted prior-year excess returns over $A D-251$ to $A D-2$, and for easier exposition, it is expressed in fractional units in Panel A and in percent units in Panel B (e.g., 0.30 and 30\%). Parent and subsidiary deficits are measured over a two-year period ending with the fiscal year of SEO by using the Frank and Goyal (2003) procedure: Deficit $=$ Dividends + Investments + Change in working capital - Internal cash flow, all normalized by the corresponding total assets. The deficits are expressed in annual units, i.e., the two-year cumulative deficit divided by two. The computation of right-hand-side variables is described in Section III. In four cases the deficit data for either the parent or the subsidiary are available only for the current year, in which case I use that in place of the two-year deficit. Panel A presents results of a multinomial probit model in columns (1) to (3), and a simple probit model in column (4). Column (1) relates to independent variables the probability of choosing SS instead of $P P$, column (2) relates the probability of choosing $S P$ instead of $P P$, and columns (3) relates the probability of choosing SP instead of SS. Column (4) also relates the probability of choosing SS instead of SP, but eliminates all cases in which divestiture motives are given. The asymptotic $t$-statistics are shown in parentheses. The notation ${ }^{*}, * *$, and ${ }^{* * *}$ denotes statistical significance at the $10 \%, 5 \%$, and $1 \%$ levels. Panel B presents the mean and median values of parent and subsidiary prior-year excess returns and annual deficits for different issue types.

Panel A: Probit models of the determinants of subsidiary primary, subsidiary secondary, and parent primary issues

\begin{tabular}{|c|c|c|c|c|}
\hline \multirow[b]{2}{*}{ Independent variables } & \multicolumn{3}{|c|}{ Multinomial probit } & \multirow{2}{*}{$\begin{array}{c}\text { Probit } \\
S P \text { vs. } S S \\
\text { Exclude cases in } \\
\text { which divestiture } \\
\text { motives are given }\end{array}$} \\
\hline & $S S$ vs. $P P$ & $S P$ vs. $P P$ & $S P$ vs. $S S$ & \\
\hline & (1) & $(2)$ & (3) & (4) \\
\hline Intercept & $\begin{array}{c}0.46 \\
(1.02)\end{array}$ & $\begin{array}{c}0.32 \\
(0.75)\end{array}$ & $\begin{array}{c}-0.14 \\
(-0.34)\end{array}$ & $\begin{array}{c}0.13 \\
(0.40)\end{array}$ \\
\hline Parent prior-year excess return & $\begin{array}{l}-1.71 \\
(-2.10)^{* *}\end{array}$ & ${ }^{-1.42}(-2.36)^{* *}$ & $\begin{array}{c}0.29 \\
(0.40)\end{array}$ & $\begin{array}{c}-0.51 \\
(-1.07)\end{array}$ \\
\hline Subsidiary prior-year excess return & $\begin{array}{c}1.55 \\
(1.37)\end{array}$ & $\begin{array}{c}1.76 \\
(1.68)^{*}\end{array}$ & $\begin{array}{c}0.20 \\
(0.45)\end{array}$ & $\begin{array}{c}0.17 \\
(0.44)\end{array}$ \\
\hline Parent annual deficit & $\begin{array}{l}-17.30 \\
(-3.20)^{* * *}\end{array}$ & $\begin{array}{c}-5.15 \\
(-1.75)^{*}\end{array}$ & $\begin{array}{l}12.14 \\
(2.45)^{* *}\end{array}$ & $\begin{array}{c}3.33 \\
(1.09)\end{array}$ \\
\hline Subsidiary annual deficit & $\begin{array}{c}2.28 \\
(1.36)\end{array}$ & $\begin{array}{l}2.85 \\
(2.25)^{* *}\end{array}$ & $\begin{array}{c}0.57 \\
(0.38)\end{array}$ & $\begin{array}{c}2.72 \\
(1.52)\end{array}$ \\
\hline
\end{tabular}

Panel B: Mean (median) values of parent and subsidiary prior returns and annual deficits for different issue types

\begin{tabular}{|c|c|c|c|c|c|}
\hline & \multirow[b]{2}{*}{$\begin{array}{c}\text { Parent } \\
\text { primary } \\
(P P)\end{array}$} & \multirow[b]{2}{*}{$\begin{array}{c}\text { Subsidiary } \\
\text { primary } \\
(S P)\end{array}$} & \multicolumn{3}{|c|}{ Subsidiary secondary (SS) } \\
\hline & & & All cases & $\begin{array}{c}\text { Divestiture } \\
\text { motives } \\
\text { given }\end{array}$ & $\begin{array}{l}\text { Divestiture } \\
\text { motives } \\
\text { not given }\end{array}$ \\
\hline Number & 20 & 32 & 25 & 13 & 12 \\
\hline Parent prior return & 44.59 ( 16.25) & $21.32(16.26)$ & $6.85(-11.06)$ & $-9.35(-6.45)$ & $24.41(-11.69)$ \\
\hline Subsidiary prior return & $7.48(0.96)$ & $53.78(33.76)$ & 32.34 ( 4.87$)$ & $25.84(-4.91)$ & 39.38 ( 20.00) \\
\hline Parent annual deficit & $0.123(0.058)$ & $0.063(0.060)$ & $-0.037(-0.022)$ & $-0.080(-0.032)$ & $0.009(0.005)$ \\
\hline Subsidiary annual deficit & $0.180(0.081)$ & $0.239(0.207)$ & $0.121(0.079)$ & $0.144(0.083)$ & $0.095(0.071)$ \\
\hline
\end{tabular}




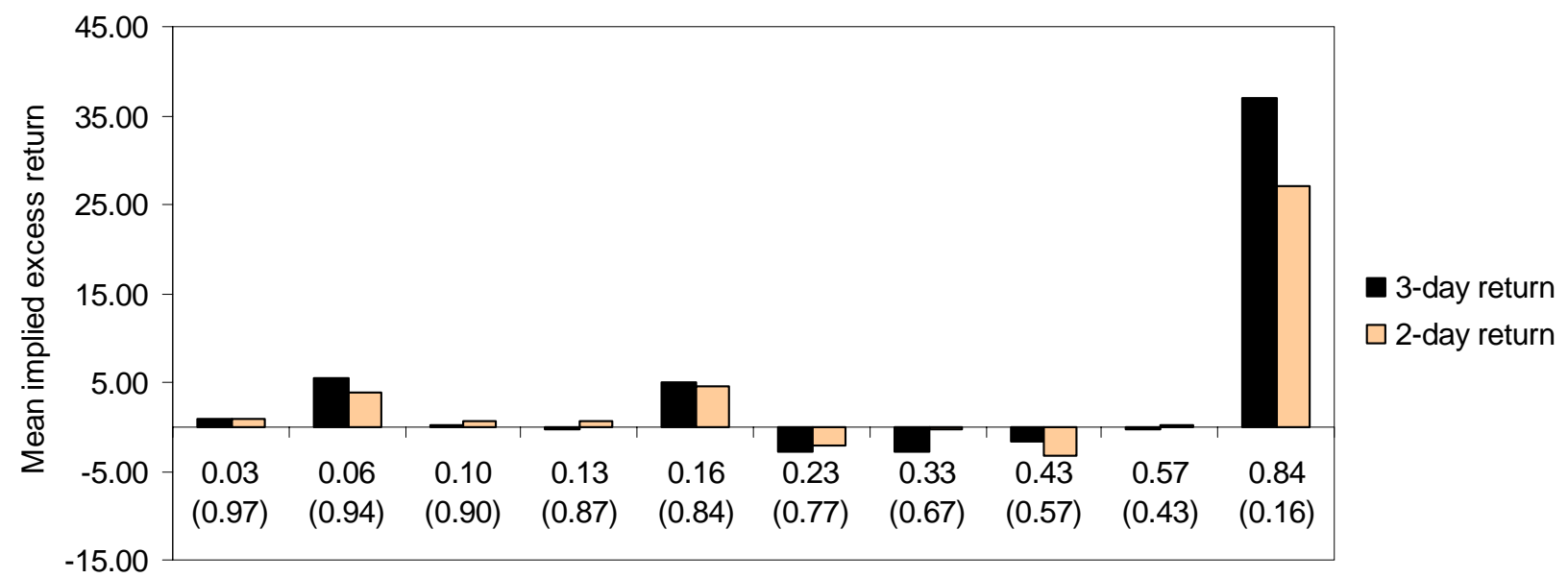

Decile portfolios formed by subsidiary equity value (conversely, nonsubsidiary equity value) divided by total equity value of parent firms

Figure 1: Implied excess returns to nonsubsidiary equity value of parent firms related to the decile rank of subsidiary equity value divided by total equity value in subsidiary seasoned equity offerings (SEOs). The first row of labels for the $\mathrm{x}$-axis shows the subsidiary equity value divided by total equity value, and the second row shows the nonsubsidiary equity value divided by total equity value. (Ignoring debt, the two quantities must sum up to 1.00.) The initial sample of 90 subsidiary SEOs made within a parent-subsidiary structure is described in Table I. However, the sample used in this figure excludes 12 cases in which the implied nonsubsidiary equity value of the parent firm is negative. The procedure of calculating implied equity values and implied excess returns is described in Section II.D. 